\title{
PPE: what now for the global supply chain?
}

Covid-19 has turned the spotlight on healthcare supply chains, challenging 30 years of ever growing globalisation, writes Jane Feinmann

\author{
Jane Feinmann freelance journalist
}

London

As 2020 dawned, the idea that a healthcare procurement team should maintain national supplies of personal protective equipment (PPE) at minimal cost to healthcare budgets was entirely uncontroversial.

"It involves opening a bid and giving the work to the lowest bidder, almost invariably a Chinese company because of cost," says Willy Shih, the Robert \& Jane Cizik professor of management practice at Harvard Business School. This race to the bottom in production costs means that companies have minimal incentives to maintain production in high cost locations or to worry about geographical diversity in production.

The rapid growth of container shipping in the 1990s reduced transport costs dramatically, while China was creating a robust trade infrastructure. As a result, high income countries achieved ever greater efficiency and lower costs in producing consumer goods, through outsourcing. Shih tells The BMJ, "When Nike moved its production to China, the German company Adidas had no choice but to follow suit—and the same pattern has occurred throughout manufacturing."

PPE was no different, with most of the world's stock made at low cost in China. Yet this apparently seamless global interdependence unravelled in just a few weeks after the covid-19 pandemic took off in Hubei province, at the centre of Chinese manufacturing.

\section{Panic and piracy}

As Chinese doctors and scientists struggled to make sense of the new virus, China became the first country to recognise that unprecedented quantities of PPE would be needed, not least to keep healthcare professionals safe. Western charities donated small quantities of protective gear to China in early spring 2020, but the obvious solution was right on its doorstep. The Chinese government soon made itself the sole customer of the major PPE making factories in its territory, ${ }^{2}$ while simultaneously buying up much of the rest of the world's supply. On 30 January, the last day with available data, China managed to import 20 million respirators and surgical masks in just 24 hours, the New York Times reported. ${ }^{3}$

It took the rest of the world a while to understand the downside of relying on somewhere else for lifesaving protective equipment—and the huge quantities that would be needed during a pandemic. In February the European Centre for Disease Prevention and Control, an EU agency based in Stockholm, estimated that a health service would need 14-24 separate sets of PPE every day for each confirmed coronavirus case, depending on whether symptoms were mild or severe. ${ }^{4}$ In March, World Health Organization modelling warned that 89 million medical masks, 76 million examination gloves, and 1.6 million pairs of goggles would be required worldwide for the covid-19 response each month, with a dire shortage putting healthcare workers at risk. ${ }^{5}$

The ensuing scrum for PPE has made daily headlines as international solidarity has taken a tumble. An RAF plane was forced to sit on an airstrip in Turkey for two days in April, waiting to pick up a shipment of 400000 protective gowns for NHS staff. Reports emerged of US purchasers brandishing cash on the runway of a Shanghai airport, buying up a cargo of masks and other PPE that was already on a plane bound for France, while in Bangkok 200000 medical face masks ordered by Berlin were allegedly confiscated by US officials. ${ }^{6}$ The German interior minister has accused the US of "modern piracy"; meanwhile, France and Germany both blocked the export of masks and gloves to Italy and Spain.

\section{Stockpiles}

In the pre-covid world, stockpiling was regarded as a poor business model in both the US and the UK, with excess capacity seen as an unnecessary expense and hospitals encouraged to seek replenishment even daily. And, although countries had emergency preparations, at least on paper, these have proved unequal to demands.

The US Strategic National Stockpile—originally called the National Pharmaceutical Stockpile and established in 
1999 —encompasses \$7bn-\$8bn (£5.7bn- £6.5bn;

$€ 6.4 \mathrm{bn}-€ 7.4 \mathrm{bn}$ ) worth of emergency supplies, mainly lifesaving drugs, held in strategically located secret stores around the country. It did include masks, but most were distributed to states and localities during the $2009 \mathrm{H} 1 \mathrm{~N} 1$ pandemic, and stocks were not replenished, said Andrew Lakoff, professor of global health and disaster response at the University of Southern California, in an interview with Vox. ${ }^{7}$

The UK's emergency stockpile, created in 2006, was part of its pandemic influenza preparedness programme. It comprises 52 000 pallets of equipment—gloves, aprons, respirator masks, and anti-flu drugs—worth an estimated $£ 500 \mathrm{~m}(€ 567 \mathrm{~m}$; $\$ 617 \mathrm{~m}$ ). It had no gowns or visors, however, despite a recommendation from the New and Emerging Respiratory Virus Threats Advisory Group (Nervtag) to build up these stocks. ${ }^{8}$ A $\mathrm{BBC}$ investigation also claimed that 21 million of 33 million vitally needed FFP3 respirator masks, which were included in the original 2009 procurement list for the stockpile, had gone missing without explanation.

Moreover, management was outsourced three years ago, and the Guardian reported that Movianto, the stockpile's current management company, was itself in the process of being sold to a large US company and subject to a legal dispute that has prevented access to the warehouse stock. ${ }^{9}$

\section{The case against globalisation}

The obvious solution to all of this is a reversal of the trend towards globalisation. Support for this comes not just from nationalist proponents of "bring manufacturing home" but from pragmatic health experts too. WHO's director general, Tedros Adhanom Ghebreyesus, has called on governments to increase domestic manufacturing of PPE by $40 \%$. Germany's health minister, Jens Spahn, has said that public health must be the number one priority and that, with demand for PPE currently high and expected to remain so in the short and medium term, the priority for Germany must be to reduce reliance on international production.

As well as taking action to boost procurement, Germany has set up a Task Force for Production Capacity and Production Processes with the job of "building up national and European value chains for PPE and active ingredients ... thereby making an essential contribution to the supply for the medium term." 10 Spahn announced on 9 April that 100 (unnamed) German companies had submitted "promising responses" to the government's call to manufacture PPE, with contracts due to be awarded from mid-August 2020 to the end of 2021.

Yet there remains scepticism that individual states can manufacture PPE efficiently even if the will is there. For a start, says Shih, it's not simply a matter of paying workers more by the hour, as it might be if the products were $\mathrm{T}$ shirts. He says, "Even something as simple as an N95 mask uses-according to the label on the box-'globally sourced materials."”

For instance, the Guardian revealed a global shortage of a particular plastic-a type of non-woven polypropylene known as melt-blown - that acts as a filter in masks. Previously not regarded as a strategic commodity, production of melt-blown has moved to low cost factories in Asia over the past three decades, and China produces half of all melt-blown in the world. Other crucial, low cost, raw materials include nose clips and another plastic called spun-bond polypropylene. Both are also produced in China.
It's these materials that make up the real supply chain. Even if they could be sourced locally, "the process of scaling up production includes setting up this complex supply chain, designing an assembly process, establishing testing and quality procedures, and countless other details," says Shih. More than two decades of reliance on globalised supply chains has left high income countries without the infrastructure and experience to manufacture and distribute PPE en masse.

Moreover, the risk with abandoning that global chain altogether, says Shih, is that more local production would lead to a more fragmented supply chain. That could lead to the bigger, more reliable suppliers disappearing because of insufficient business, leaving behind a less experienced, less stable group of suppliers that would be risky to rely on in another global emergency.

Shih draws parallels with a Bill \& Melinda Gates Foundation initiative intended to simplify the manufacture of vaccines for children. ${ }^{11}$ Its funding enabled low income countries to build their own factories and provide affordable vaccines for their populations. But this approach could also unintentionally undermine "high standards of production and quality control procedures critical to protect the integrity of the global vaccine supply ... while encouraging more developed countries' manufacturers to exit the market," says Shih.

With PPE, little can change for now. But at the very least, the pandemic, combined with recent trade wars between China and the US, has exposed the brittleness of our global supply chains and trading systems, as well as the dire state of emergency stockpiles. For the health of frontline staff, we need to build more resilience into these operations.

Competing interests: I have read and understood BMJ policy on declaration of interests and have no relevant interests to declare.

Provenance and peer review: Commissioned; not externally peer reviewed.

1 Shih WC. Bringing manufacturing back to the US is easier said than done. Harvard Bus Rev 2020 Apr 15. https://hbr.org/2020/04/bringing-manufacturing-back-to-the-u-s-is-easiersaid-than-done.

2 Subramanian S. How the face mask became the world's most coveted commodity. Guardian 2020 Apr 28. https://www.theguardian.com/world/2020/apr/28/face-maskscoveted-commodity-coronavirus-pandemic.

3 Bradsher K, Alderman L. The world needs masks. China makes them, but has been hoarding them. New York Times 2020 Mar 13. https://www.nytimes.com/2020/03/13/ business/masks-china-coronavirus.html.

4 European Centre for Disease Prevention and Control. Coronavirus disease 2019 (COVID-19) pandemic: increased transmission in the EU/EEA and the UK-seventh update. 25 Mar 2020. https://www.ecdc.europa.eu/sites/default/files/documents/RRAseventh-update-Outbreak-of-coronavirus-disease-COVID-19.pdf.

5 World Health Organization. Shortage of personal protective equipment endangering health workers worldwide. 3 Mar 2020. https://www.who.int/news-room/detail/03-03-2020shortage-of-personal-protective-equipment-endangering-health-workers-worldwide.

6 US firm denies German "piracy" claims over vanished face masks. DW News 2020 Apr 4. https://www.dw.com/en/us-firm-denies-german-piracy-claims-over-vanished-face-masks/ a-53017112.

7 Estes AC. Trump's Strategic National Stockpile looks empty amid ventilator, mask, and PPE shortage. Vox 2020 Apr 7. https://www.vox.com/recode/2020/4/3/21206170/usemergency-stockpile-jared-kushner-almost-empty-coronavirus-medical-supplies-ventilators.

8 Coronavirus: UK failed to stockpile crucial PPE. BBC News 2020 Apr 20. https://www. bbc.co.uk/news/newsbeat-52440641.

9 Davies H. Revealed: Private firm running UK PPE stockpile was sold in middle of pandemic. Guardian 2020 Apr 22. https://www.theguardian.com/world/2020/apr/22/revealed-privatefirm-running-uk-ppe-stockpile-was-sold-in-middle-of-pandemic.

10 Federal Ministry for Economic Affairs and Energy. Federal Government fosters and boosts production of medical personal protection equipment. 9 Apr 2020. https://www.bmwi.de/ Redaktion/EN/Pressemitteilungen/2020/20200409-federal-government-fosters-and-bootsproduction-of-medical-personal-protection-equipment.html.

11 Shin WC. Bill \& Melinda Gates Foundation: shaping the vaccine manufacturing ecosystem. Harvard Business School Case 620-021. 16 Sep 2019. https://gatesopenresearch.org/ documents/3-1619.

Published by the BMJ Publishing Group Limited. For permission to use (where not already granted under a licence) please go to http://group.bmj.com/group/rights-licensing/ permissions 